\title{
EFFECT OF DIFFERENT POTASSIUM SOIL LEVELS AND FORMS OF POTASSIUM FERTILIZERS ON MICRO-ELEMETAL NUTRION STATUS OF APPLE TREES IN EARLY FRUITION PERIOD
}

\author{
Adam Szewczuk ${ }^{1}$, Andrzej Komosa ${ }^{2}$, \\ Ewelina Gudarowska ${ }^{1}$ \\ ${ }^{1}$ Chair of Horticulture \\ Wroclaw University of Environmental and Life Sciences \\ ${ }^{2}$ Chair of Horticultural Plant Nutrition \\ Poznań University of Life Sciences
}

\begin{abstract}
The experiment was established in the spring of 1999 on grey brown podsolic soil formed from boulder clay. Apple trees of cv. Golden Delicious were planted on rootstock at $3.5 \times 1.2 \mathrm{~m}\left(2381\right.$ trees $\left.\cdot \mathrm{ha}^{-1}\right)$. The first factor in the experiment consisted of the levels of potassium in the arable soil layer: 120,160 and $200 \mathrm{mg} \mathrm{K} \cdot \mathrm{kg}^{-1}$ of soil d.m., on the basis of annual chemical analyses and determined by universal method. The second factor comprised three forms of potassium fertilizers: potassium chloride (KCl-60\%), potassium sulphate $\left(\mathrm{K}_{2} \mathrm{SO}_{4}\right)$ and potassium nitrate $\left(\mathrm{KNO}_{3}\right)$. Each year the analyses of macro- and microelements in the soil and leaves were made.

The increase in available potassium levels from 120 to $200 \mathrm{mg} \mathrm{K} \cdot \mathrm{kg}^{-1}$ of soil d.m did not have influence on the content of available forms of iron, manganese, zinc, copper and boron in the herbicide fallow strips in the tree rows or in the arable $(0-20 \mathrm{~cm})$ and subarable $(20-40 \mathrm{~cm})$ soil layers. Application of potassium sulphate fertilizer caused a significant increase in the content of zinc in herbicide strips in both soil layers compared with potassium chloride and potassium nitrate. Different potassium fertilizer forms did not cause any significant changes in amounts of available forms of iron, manganese, copper and boron.
\end{abstract}

dr hab. Adam Szewczuk, Chair of Horticulture, Wroclaw University of Environmental and Life Sciences, pl. Grunwaldzki 24A, 50-363 Wrocław, phone (071) 32017 39, e-mail: adam.szewczuk@up.wroc.pl 
The increase in available potassium levels from 120 to $200 \mathrm{mg} \mathrm{K} \cdot \mathrm{kg}^{-1}$ of soil d.m significantly reduced the content of manganese in leaves of trees. However, no significant influence on the content of iron, zinc, copper and boron in leaves of apple trees was found.

Key words: apple trees, potassium fertilizers, chlorides, sulphates, nitrates, microelements.

\title{
WPŁYW RÓŻNYCH POZIOMÓW POTASU I RODZAJU NAWOZÓW POTASOWYCH NA STAN ODŻYWIENIA JABŁONI MIKROELEMENTAMI PO WEJŚCIU DRZEW W OKRES OWOCOWANIA
}

\begin{abstract}
Abstrakt
Doświadczenie założono wiosną 1999 r. na glebie płowej wytworzonej z glin lekkich zwałowych. Drzewa odmiany Golden Delicious na podkładce M.26 posadzono w rozstawie $3,5 \times 1,2 \mathrm{~m}\left(2381 \mathrm{drzew} \cdot \mathrm{ha}^{-1}\right)$. Pierwszym czynnikiem badań był zróżnicowany poziom zawartości potasu: 120,160 i $200 \mathrm{mg} \mathrm{K} \cdot \mathrm{kg}^{-1} \mathrm{w}$ ornej warstwie gleby, oznaczonego metoda uniwersalna, drugim rodzaj zastosowanego nawozu potasowego: chlorek potasu (sól potasowa 60\%), siarczan potasu i saletra potasowa. Corocznie wykonywano analizy gleb i liści na zawartość mikroelementów.

Wzrost zawartości przyswajalnych form potasu w zakresie $120-200 \mathrm{mg} \mathrm{K} \cdot \mathrm{kg}^{-1}$ gleby nie miał istotnego wpływu na zawartość przyswajalnych form żelaza, manganu, cynku, miedzi i boru w pasach herbicydowych gleby, zarówno w warstwie 0-20, jak i 20-40 cm. Stosowanie siarczanu potasu istotnie zwiększało zawartość cynku w pasach herbicydowych zarówno w warstwie 0-20, jak i 20-40 cm gleby w stosunku do chlorku potasu (sól potasowa $60 \%$ ) i azotanu potasu (saletra potasowa). Nie stwierdzono wpływu form nawozów potasowych na zawartość przyswajalnych form żelaza, manganu, miedzi i boru w glebie.

Wzrost zawartości przyswajalnych form potasu w glebie w zakresie $120-200 \mathrm{mg} \mathrm{K} \cdot \mathrm{kg}^{-1}$ gleby istotnie zmniejszał zawartość manganu w liściach jabłoni. Nie wykazano natomiast wpływu wzrastających poziomów potasu w glebie na zawartość w liściach jabłoni żelaza, manganu, miedzi i boru.
\end{abstract}

Słowa kluczowe: jabłoń, potas, nawozy potasowe, chlorki, siarczany, azotany, mikroelementy.

\section{INTRODUCTION}

Fertilization is the most important condition for proper growth and yielding of trees. Optimal nutrient supply for trees should take into account the vigour of the tree growth, the level of yielding as well the nutrient content in the soil and in the plant. Potassium fertilization and favourable N/K ratio can increase the frost tolerance of generative organs of fruit trees to some extent. The excess of lime can be compensated by potassium fertilization (SzÜCs 2005). Potassium is taken up by apple trees in high levels, even greater than is actually needed to grow and yield properly. Excessive amounts of potassium in soil can cause worse absorption of magnesium (LIPECKI and JADCZUK 1998, PiETRANEK and JADCZUK 2005) and calcium. Research on potassium fertilization of apple trees has brought variable re- 
sults. LeSZCZYŃSKI and SADOWSKI (1990) pointed out to the positive effects of K fertilization on the tree nutrient status, while PACHOLAK (1984) presented an opposite opinion.

The content of potassium and phosphorus for orchard soil is usually determined by Egner-Riehm's method and the content of magnesium by Schachtschabel's method. In horticulture, a universal method after Nowosielski is used for determining all macro- and microelements. Komosa and STAFECKA (2002) found out that the universal method is good for orchard soils, too. Most often, potassium is applied as potassium chloride. Being more expensive, potassium sulfate is used rarely. However, some studies conducted in Poland indicated a low sulfur level in soils of farmlands as well as in orchards (JAKUBUS 2001). That is why, using potassium sulfate for fertilization in apple orchard could by an important source of sulfur (Komosa, SzewCzUK 2002, SzEWCZUK et al. 2008).

The aim of the present research has been to determine the influence of different level of potassium fertilization, as well anion accompanying potassium: chlorides, nitrites, sulfates, on the content of microelements in leaves of cv. Golden Delicious apple trees and on their nutrition status.

\section{MATERIAL AND METHODS}

The experiment was carried out in 2002-2004 years in the Experimental Station belonging to Wrocław University of Environmental and Life Sciences. In the spring of 1999, two-year-old apple trees of cv. Golden Delicious on rootstock M 26 were planted at the spacing $3.5 \times 1.2 \mathrm{~m}\left(2381\right.$ trees $\left.^{-1}\right)$ on grey brown podsolic soil formed from boulder clay. The experiment was established in a randomized split-plot design in four replications with 4 trees per plot. The experimental plot covered $67.2 \mathrm{~m}^{2}$ and had 16 trees, of which 4 in the middle were studied and the remaining 12 made the isolation.

Herbicide fallow strips were in the tree rows grass alleys were maintained and between them. Before planting, the macro- and microelements content of the soil was determined (Table 1). According to the content index worked out by Komosa and STAFECKA (2002), the following were established: $\mathrm{N}-\mathrm{NH}_{4}+\mathrm{N}_{-} \mathrm{NO}_{3}$ 6-20, P 30-60, K 50-80, Ca 250-400, Mg 30.0-60 and $\mathrm{S}_{-} \mathrm{SO}_{4}$ 10-30 $\mathrm{mg} \cdot \mathrm{kg}^{-1} \mathrm{~g}$ soil d.w. and Fe 75.0-120.0, Mn 25.0-40.0, Zn 3.0-6.0, Cu 1.0-4.0 and B 0.3-1.5 mg. $\mathrm{kg}^{-1}$ soil d.m. and $<50 \mathrm{mg} \mathrm{Cl},<50 \mathrm{mg} \mathrm{Na} \cdot \mathrm{kg} \mathrm{g}^{-1}$ soil, EC $<0.5 \mathrm{mS} \cdot \mathrm{cm}^{-1}$, i.e. low contents of nitrogen, sulfur and iron, standard amounts of phosphorus, manganese, copper and boron, high contents of potassium, magnesium, calcium, zinc, chloride and an admissible level of sodium in the arable soil layer $(0-20 \mathrm{~cm})$. In the subarable soil layer $(20-$ $-40 \mathrm{~cm}$ ), low contents of nitrogen, phosphorus, potassium, sulfur, zinc and copper, medium levels of calcium, magnesium, iron, manganese and boron, 
Table 1

Content of macro and microelements in the soil before planting of apple trees (1998)

\begin{tabular}{|c|c|c|c|c|c|c|c|}
\hline \multirow{2}{*}{$\begin{array}{c}\text { The soil } \\
\text { layer } \\
(\mathrm{cm})\end{array}$} & \multicolumn{7}{|c|}{$\mathrm{mg} \cdot \mathrm{kg}^{-1}$ soil d.w. } \\
\hline & $\mathrm{N}-\mathrm{NH}_{4}$ & $\mathrm{~N}-\mathrm{NO}_{3}$ & $\mathrm{P}$ & $\mathrm{K}$ & $\mathrm{Ca}$ & $\mathrm{Mg}$ & $\mathrm{S}-\mathrm{SO}_{4}$ \\
\hline $\begin{array}{c}0-20 \\
20-40\end{array}$ & $\begin{array}{c}3.1 \\
\text { t.a.* }\end{array}$ & $\begin{array}{c}23.4 \\
5.5\end{array}$ & $\begin{array}{c}38.0 \\
17\end{array}$ & $\begin{array}{c}96.0 \\
22\end{array}$ & $\begin{array}{c}1278 \\
279\end{array}$ & $\begin{array}{c}86.0 \\
42\end{array}$ & $\begin{array}{l}\text { t.a. } \\
\text { t.a. }\end{array}$ \\
\hline \multicolumn{8}{|c|}{$\mathrm{mg} \cdot \mathrm{kg}^{-1}$ soil d.w. } \\
\hline & $\mathrm{Fe}$ & $\mathrm{Zn}$ & $\mathrm{Mn}$ & $\mathrm{Cu}$ & $\mathrm{B}$ & $\mathrm{Na}$ & $\mathrm{Cl}$ \\
\hline \multirow[t]{2}{*}{$\begin{array}{c}0-20 \\
20-40\end{array}$} & $\begin{array}{l}66.4 \\
72.9\end{array}$ & $\begin{array}{l}9.3 \\
2.5\end{array}$ & $\begin{array}{l}25.3 \\
39.2\end{array}$ & $\begin{array}{l}2.9 \\
0.9\end{array}$ & $\begin{array}{l}0.77 \\
0.50\end{array}$ & $\begin{array}{l}6 \\
4\end{array}$ & $\begin{array}{l}55 \\
63\end{array}$ \\
\hline & $\mathrm{pH}\left(\mathrm{H}_{2} \mathrm{O}\right)$ & $\begin{array}{c}\mathrm{EC} \\
\mathrm{mS} \cdot \mathrm{cm}^{-1}\end{array}$ & & & & & \\
\hline $\begin{array}{c}0-20 \\
20-40\end{array}$ & $\begin{array}{l}6.99 \\
6.98\end{array}$ & $\begin{array}{l}0.22 \\
0.28\end{array}$ & & & & & \\
\hline
\end{tabular}

t.a.* trace amounts

and high content of chlorides, $\mathrm{pH}\left(\right.$ in $\left.\mathrm{H}_{2} \mathrm{O}\right) 6.99$ and 6.98 , EC $0.22(0-20 \mathrm{~cm})$ and $0.18 \mathrm{mS} \cdot \mathrm{cm}^{-1}(20-40 \mathrm{~cm})$ were observed.

The field trail was established as a two-factor experiment. The first factor consisted of increasing levels of potassium in the arable soil layer: 120, 160 and $200 \mathrm{mg} \mathrm{K} \cdot \mathrm{kg}^{-1}$ soil d.m., based on annual chemical analyses. The second factor comprised three forms of potassium fertilizers: potassium chloride $(\mathrm{KCl})$, potassium sulfate $\left(\mathrm{K}_{2} \mathrm{SO}_{4}\right)$ and potassium nitrate $\left(\mathrm{KNO}_{3}\right)$. The assumed level of potassium was kept by using different rates of fertilizers (Table 2). All treatments were fertilized with nitrogen and phosphorus, according to the annual analyses of soil and leaves. Nitrogen was used as ammonium nitrate (34\%) and saltpetre (13\% N, 39\% K-only in combination

Table 2

Rates of potassium fertilizers in 2002-2004 $\left(\mathrm{mg} \cdot \mathrm{kg}^{-1}\right)$

\begin{tabular}{|l|c|c|c|c|c|c|}
\hline Treatment & $\begin{array}{c}\mathrm{K} \text { level } \\
\left(\mathrm{mg} \cdot \mathrm{kg}^{-1} \text { soil }\right)\end{array}$ & $\begin{array}{c}\text { Fertilizer } \\
\text { form }\end{array}$ & $\begin{array}{c}\text { Sum from } \\
1999-2001\end{array}$ & 2002 & 2003 & 2004 \\
\hline $\mathrm{K}-1(\mathrm{KCl})$ & 120 & $\mathrm{KCl}$ & 54 & 125 & 0 & 0 \\
\hline $\mathrm{K}-2(\mathrm{KCl})$ & 160 & $\mathrm{KCl}$ & 154 & 170 & 129 & 0 \\
\hline $\mathrm{K}-3(\mathrm{KCl})$ & 200 & $\mathrm{KCl}$ & 254 & 100 & 0 & 75 \\
\hline $\mathrm{K}-1\left(\mathrm{~K}_{2} \mathrm{SO}_{4}\right)$ & 120 & $\mathrm{~K}_{2} \mathrm{SO}_{4}$ & 54 & 36 & 0 & 75 \\
\hline $\mathrm{K}-2\left(\mathrm{~K}_{2} \mathrm{SO}_{4}\right)$ & 160 & $\mathrm{~K}_{2} \mathrm{SO}_{4}$ & 192 & 40 & 36 & 0 \\
\hline $\mathrm{K}-3\left(\mathrm{~K}_{2} \mathrm{SO}_{4}\right)$ & 200 & $\mathrm{~K}_{2} \mathrm{SO}_{4}$ & 314 & 186 & 0 & 0 \\
\hline $\mathrm{K}-1\left(\mathrm{KNO}_{3}\right)$ & 120 & $\mathrm{KNO}_{3}$ & 54 & 123 & 94 & 0 \\
$\mathrm{~K}-2\left(\mathrm{KNO}_{3}\right)$ & 160 & $\mathrm{KNO}_{3}$ & 154 & 177 & 0 & 0 \\
$\mathrm{~K}-3\left(\mathrm{KNO}_{3}\right)$ & 200 & $\mathrm{KNO}_{3}$ & 254 & 277 & 0 & 150 \\
\hline
\end{tabular}


with $\mathrm{KNO}_{3}$ ), phosphorus as triple superphosphate $(20 \% \mathrm{P})$, potassium as potassium chloride $(60 \%)$, potassium sulfate $(41 \%)$. The fertilization was applied in the middle of March, April and May.

Soil samples from the herbicide strips of each plot were collected each year in the second half of July, separately from the layers 0-20 and 20$-40 \mathrm{~cm}$, by using a soil drill. Soil analyses were carried out using the universal method according to Nowosielski (1974), modified for orchard soils (KoMOSA and StAFEckA, 2002). In this method, B was extracted in $0.03 \mathrm{M}$ $\mathrm{CH}_{3} \mathrm{COOH}$, microelements $\mathrm{Fe}, \mathrm{Mn}, \mathrm{Zn}$ and $\mathrm{Cu}$ were extracted with Lindsay's solution, which contained in $1 \mathrm{dm}^{-3}: 5 \mathrm{~g} \mathrm{EDTAH}_{4}, 9.0 \mathrm{ml} 25 \%$ ammonia, $4 \mathrm{~g}$ citric acid, $2 \mathrm{~g}\left(\mathrm{CH}_{3} \mathrm{COO}\right)_{2} \mathrm{Ca} \cdot 2 \mathrm{H}_{2} \mathrm{O}$. Extractions were conducted in a 1:4 proportion of soil to extraction solution, (50 g dry weight soil and 200 $\mathrm{cm}^{3}$ Lindsay's solution) for 30 minutes. After extraction, B was assessed by colorimetric analysis with curcuma, and $\mathrm{Fe}, \mathrm{Mn}, \mathrm{Zn}$ i $\mathrm{Cu}$ - by the AAS method (Laboratory research method... 1983).

Leaf samples were collected in the middle of July. One sample containing 100 leaves from the middle part of long-shoots (3-4 leaves per shoot) was collected from each plot. The concentration of $\mathrm{Fe}, \mathrm{Mn}, \mathrm{Zn}, \mathrm{Cu}$ and $\mathrm{B}$ in the leaves was estimated. Mineralization of leaves for $\mathrm{Fe}, \mathrm{Mn}, \mathrm{Zn}$ and $\mathrm{Cu}$ assessment was performed in a mixture of $\mathrm{HNO}_{3}, \mathrm{HClO}_{4}$ and $\mathrm{H}_{2} \mathrm{SO}_{4}$ in the 10:1:1 ratio, while concentration of $\mathrm{B}$ was determined after dry digestion with calcium hydroxide (Laboratory research method... 1972).

The results were evaluated statistically using the analysis of variance. The significance of differences between means was evaluated according to $t$-Duncan's multiple range test at $P=0.05$.

The present study is the continuation of a previous experiment carried out in order to estimate the influence of different potassium fertilization on macro- and microelement nutrition status of young apple trees. The results, for 1991-2001 year, were published by Komosa and Szewczuk (2002). In this study, the results for the next three years are presented and concern older trees in full fruition period.

\section{RESULTS AND DISSCUSION}

The results presented in Table 3 proved that increasing potassium in arable soil layer in herbicide fallow had no influence on the content of available forms of iron, manganese, zinc, cooper and boron in soil. However, significant influence of the fertilizer forms of potassium on the content of zinc in the arable soil layer was noted (Table 3). The application of potassium sulfate caused the highest zinc content in soil, in comparison with potassium chloride and nitrate form. These differences were confirmed by the estimation of the content of available forms of microelements in the subarable 
Table 3

Content of microelements in the soil layer of $0-20 \mathrm{~cm}$ in the herbicide strips in relation to fertilizer form and potassium level in soil (means from 2002-2004)

\begin{tabular}{|c|c|c|c|c|}
\hline \multirow{2}{*}{$\begin{array}{c}\mathrm{K} \text { level } \\
\mathrm{mg} \cdot \mathrm{kg}^{-1} \text { of soil }\end{array}$} & \multicolumn{3}{|c|}{ Fertilizer form } & \multirow{2}{*}{ Mean } \\
\hline & $\mathrm{KCl}$ & $\mathrm{K}_{2} \mathrm{SO}_{4}$ & $\mathrm{KNO}_{3}$ & \\
\hline \multicolumn{5}{|c|}{$\mathrm{mg} \cdot \mathrm{Fe} \mathrm{kg}{ }^{-1}$ of soil } \\
\hline 120 & $76.7^{* * *}$ & 74.4 & 76.2 & $75.7^{* *}$ \\
\hline 160 & 79.4 & 74.4 & 77.6 & 77.1 \\
\hline 200 & 68.3 & 69.0 & 56.9 & 64.7 \\
\hline Means & $74.8 *$ & 72.6 & 70.2 & \\
\hline \multicolumn{5}{|c|}{$\mathrm{mg} \cdot \mathrm{Mn} \mathrm{kg}{ }^{-1}$ of soil } \\
\hline 120 & $21.1^{* * *}$ & 21.4 & 17.1 & $19.9 * *$ \\
\hline 160 & 19.2 & 16.8 & 26.5 & 20.8 \\
\hline 200 & 25.1 & 19.5 & 11.7 & 18.8 \\
\hline Means & $21.8^{*}$ & 19.2 & 18.4 & \\
\hline \multicolumn{5}{|c|}{$\mathrm{mg} \cdot \mathrm{Zn} \mathrm{kg}^{-1}$ of soil } \\
\hline 120 & $6.2 \mathrm{ab}$ & $17.1 \mathrm{~cd}$ & $8.8 \mathrm{abc}$ & $10.7 \mathrm{ab}$ \\
\hline 160 & $6.3 \mathrm{ab}$ & $16.0 \mathrm{~cd}$ & $5.3 \mathrm{ab}$ & $9.2 \mathrm{a}$ \\
\hline 200 & $6.2 \mathrm{ab}$ & $16.5 \mathrm{~cd}$ & $5.2 \mathrm{a}$ & $9.3 \mathrm{a}$ \\
\hline Means & $6.2 \mathrm{ab}$ & $15.5 \mathrm{~cd}$ & $6.4 \mathrm{ab}$ & \\
\hline \multicolumn{5}{|c|}{$\mathrm{mg} \cdot \mathrm{Cu} \mathrm{kg}^{-1}$ of soil } \\
\hline 120 & $2.7 * * *$ & 2.8 & 2.6 & $2.7^{* *}$ \\
\hline 160 & 2.6 & 2.7 & 2.9 & 2.7 \\
\hline 200 & 3.1 & 2.7 & 2.3 & 2.7 \\
\hline Means & $2.8^{*}$ & 2.8 & 2.6 & \\
\hline \multicolumn{5}{|c|}{$\mathrm{mg} \cdot \mathrm{B} \mathrm{kg}^{-1}$ of soil } \\
\hline 120 & $0.56^{* * *}$ & 0.54 & 0.52 & $0.54^{* *}$ \\
\hline 160 & 0.52 & 0.50 & 0.48 & 0.50 \\
\hline 200 & 0.62 & 0.50 & 0.46 & 0.53 \\
\hline Means & $0.57 *$ & 0.51 & 0.49 & \\
\hline
\end{tabular}

Means marked by the same letter are not significantly different at $\alpha=0.05$.

*no significant differences between the means for the fertilizer forms

**no significant differences between the means for the potassium levels

***no significant differences for the interaction fertilizer form $\mathrm{x}$ potassium level 
Table 4

Content of microelements in the soil layer of $20-40 \mathrm{~cm}$ in the herbicide strips in relation to fertilizer form and potassium level in soil (means from 2002-2004)

\begin{tabular}{|c|c|c|c|c|}
\hline \multirow{2}{*}{$\begin{array}{c}\mathrm{K} \text { level } \\
\mathrm{mg} \cdot \mathrm{kg}^{-1} \text { of soil }\end{array}$} & \multicolumn{3}{|c|}{ Fertilizer form } & \multirow{2}{*}{ Mean } \\
\hline & $\mathrm{KCl}$ & $\mathrm{K}_{2} \mathrm{SO}_{4}$ & $\mathrm{KNO}_{3}$ & \\
\hline \multicolumn{5}{|c|}{$\mathrm{mg} \cdot \mathrm{Fe} \mathrm{kg}{ }^{-1}$ of soil } \\
\hline 120 & $74.1^{* * *}$ & 81.4 & 79.0 & $78.2^{* *}$ \\
\hline 160 & 75.0 & 58.5 & 74.8 & 69.4 \\
\hline 200 & 75.3 & 64.5 & 58.6 & 66.2 \\
\hline Means & $74.8^{*}$ & 68.1 & 70.8 & - \\
\hline \multicolumn{5}{|c|}{$\mathrm{mg} \cdot \mathrm{Mn} \mathrm{kg} \mathrm{kg}^{-1}$ of soil } \\
\hline 120 & $21.5^{* * *}$ & 23.4 & 16.7 & $20.5^{* *}$ \\
\hline 160 & 11.6 & 10.6 & 19.8 & 14.0 \\
\hline 200 & 23.4 & 12.8 & 7.9 & 14.7 \\
\hline Means & $18.8^{*}$ & 15.6 & 14.8 & - \\
\hline \multicolumn{5}{|c|}{$\mathrm{mg} \cdot \mathrm{Zn} \mathrm{kg}{ }^{-1}$ of soil } \\
\hline 120 & $4.5 \mathrm{ab}$ & $14.4 \mathrm{bc}$ & $8.0 \mathrm{ab}$ & $9.0 \mathrm{ab}$ \\
\hline 160 & $4.7 \mathrm{ab}$ & $12.7 \mathrm{abc}$ & $4.4 \mathrm{ab}$ & $7.3 \mathrm{a}$ \\
\hline 200 & $4.6 \mathrm{ab}$ & $19.9 \mathrm{c}$ & $3.4 \mathrm{a}$ & $9.3 b$ \\
\hline Means & $4.6 \mathrm{ab}$ & $15.7 \mathrm{c}$ & $5.3 \mathrm{a}$ & - \\
\hline \multicolumn{5}{|c|}{$\mathrm{mg} \cdot \mathrm{Cu} \mathrm{kg}^{-1}$ of soil } \\
\hline 120 & $2.4^{* * *}$ & 2.5 & 2.3 & $2.4^{* *}$ \\
\hline 160 & 2.2 & 2.3 & 2.5 & 2.3 \\
\hline 200 & 2.7 & 2.2 & 2.1 & 2.3 \\
\hline Means & $2.4^{*}$ & 2.4 & 2.3 & - \\
\hline \multicolumn{5}{|c|}{$\mathrm{mg} \cdot \mathrm{B} \mathrm{kg} \mathrm{k}^{-1}$ of soil } \\
\hline 120 & $0.39 * * *$ & 0.38 & 0.47 & $0.41 * *$ \\
\hline 160 & 0.43 & 0.39 & 0.42 & 0.42 \\
\hline 200 & 0.46 & 0.43 & 0.41 & 0.42 \\
\hline Means & $0.43^{*}$ & 0.40 & 0.44 & - \\
\hline
\end{tabular}

Means marked by the same letter are not significantly different at $\alpha=0.05$.

*no significant differences between the means for the fertilizer forms

***no significant differences between the means for the potassium levels

***no significant differences for the interaction fertilizer form $\mathrm{x}$ potassium level 
Table 5

Content of microelements in Golden Delicious apple leaves in relation to potassium level and fertilizer form in soil (means from 2002-2004)

\begin{tabular}{|c|c|c|c|c|}
\hline \multirow{2}{*}{$\begin{array}{c}\text { K level } \\
\mathrm{mg} \cdot \mathrm{kg}^{-1} \text { of soil }\end{array}$} & \multicolumn{3}{|c|}{ Fertilizer form } & \multirow{2}{*}{ Mean } \\
\hline & $\mathrm{KCl}$ & $\mathrm{K}_{2} \mathrm{SO}_{4}$ & $\mathrm{KNO}_{3}$ & \\
\hline \multicolumn{5}{|c|}{$\mathrm{mg} \cdot \mathrm{Fe} \mathrm{kg}^{-1}$ of soil } \\
\hline 120 & $69.1 * * *$ & 70.6 & 71.4 & $70.3^{* *}$ \\
\hline 160 & 70.3 & 74.7 & 68.1 & 71.0 \\
\hline 200 & 72.4 & 69.6 & 74.3 & 72.1 \\
\hline Means & $70.6^{*}$ & 71.6 & 71.3 & - \\
\hline \multicolumn{5}{|c|}{$\mathrm{mg} \cdot \mathrm{Mn} \mathrm{kg}^{-1}$ of soil } \\
\hline 120 & $120.1^{* * *}$ & 112.7 & 131.6 & $121.5 \mathrm{~b}$ \\
\hline 160 & 111.1 & 112.2 & 104.7 & $109.3 \mathrm{ab}$ \\
\hline 200 & 101.5 & 97.7 & 100.0 & $99.7 \mathrm{a}$ \\
\hline Means & $110.9 *$ & 107.6 & 112.1 & - \\
\hline \multicolumn{5}{|c|}{$\mathrm{mg} \cdot \mathrm{Zn} \mathrm{kg}^{-1}$ of soil } \\
\hline 120 & $36.0^{* * *}$ & 37.7 & 40.0 & $37.9^{* *}$ \\
\hline 160 & 34.8 & 39.9 & 35.4 & 36.7 \\
\hline 200 & 35.2 & 47.4 & 35.1 & 39.2 \\
\hline Means & $35.3^{*}$ & 41.7 & 36.8 & - \\
\hline \multicolumn{5}{|c|}{$\mathrm{mg} \cdot \mathrm{Cu} \mathrm{kg}^{-1}$ of soil } \\
\hline 120 & $6.7^{* * *}$ & 6.5 & 6.6 & $6.6^{* *}$ \\
\hline 160 & 6.8 & 7.0 & 6.4 & 6.7 \\
\hline 200 & 6.5 & 6.4 & 6.5 & 6.5 \\
\hline Means & $6.7^{*}$ & 6.6 & 6.5 & - \\
\hline \multicolumn{5}{|c|}{$\mathrm{mg} \cdot \mathrm{B} \mathrm{kg}^{-1}$ of soil } \\
\hline 120 & $40.9^{* * *}$ & 39.7 & 39.3 & $40.0 * *$ \\
\hline 160 & 44.0 & 43.7 & 41.7 & 43.2 \\
\hline 200 & 42.2 & 41.4 & 44.3 & 42.7 \\
\hline Means & $42.4^{*}$ & 41.6 & 41.8 & - \\
\hline
\end{tabular}

Means marked by the same letter are not significantly different at $\alpha=0.05$.

*no significant differences between the means for the fertilizer forms

**no significant differences between the means for the potassium levels

***no significant differences for the interaction fertilizer form $\mathrm{x}$ potassium level

layer of soil in herbicide fallow strips (Table 4). Significantly the highest concentration of zinc was in the soil fertilized with the sulfate form of potassium fertilizers. 
At the lower level of 120 and $160 \mathrm{mg} \mathrm{K} \mathrm{mg} \mathrm{kg}^{-1}$ of soil, the tendency to increase the content of iron, manganese and zinc in arable and subarable soil layer in herbicide fallow strips was noted. This relationship was not observed for copper and boron (Tables 3, 4).

Comparison with the content index for soils in apple orchards, worked out by Komosa and Stafecka (2002), suggested that maintaining high level of potassium in soil $\left(200 \mathrm{~K} \mathrm{mg} \cdot \mathrm{kg}^{-1}\right)$, impoverished the soil of iron (change for medium into low content), manganese and zinc (no change of class content). Content of copper and boron in soil was on the medium level, regardless of the levels of potassium content in soil. Reduction of the content of iron, manganese and zinc in soil, caused by the high level of potassium, can be connected with displacing these cations from sorption complex of soil and moving them into the depth of soil profile. Reduction of content of manganese in soil by the high level of potassium $\left(200 \mathrm{mg} \mathrm{K} \cdot \mathrm{kg}^{-1}\right)$ was confirmed by significant reduction of concentration of manganese in apple leaves.

The optimal concentration of manganese in apple leaves is $41-100 \mathrm{mg}$ $\mathrm{Mn} \cdot \mathrm{kg}^{-1}$. In the present study, the content of manganese fell from high level of content $\left(109.3-121.5 \mathrm{mg} \cdot \mathrm{kg}^{-1}\right)$ to the optimal level $-99.7 \mathrm{mg} \cdot \mathrm{kg}^{-1}$. No significant influence of the potassium level and potassium fertilizer forms on the nutritional status of iron, zinc, copper and boron of apple trees occurred. Similar results were obtained by GASTOŁ and SKRZYŃSKI (2006). According to these authors, the distribution of mineral constituents in plants depended on different organs of apple tree. It is obviously attributable to the different functions of particular fruit tree organs. GASTOE and SKRZYŃSKI [2006] did not notice the influence of dwarfing methods on leaf iron, zinc and copper content. However, different levels of microelements were noted in roots, wood and bark of apple trees (GASTOE and SkrzYŃsKI 2006). The determined content of microelements in this study was low for iron and optimal for zinc, copper and boron in comparison with the optimal contents in leaves of apple trees. The low content of iron in leaves cold be caused by high $\mathrm{pH}_{\left(\mathrm{H}_{2} \mathrm{O}\right)}$ of soil (6.98-6.99), and thus by worse uptake of iron by plants.

\section{CONCLUSIONS}

1. The increase in the content of available potassium forms from 120 to $200 \mathrm{mg} \cdot \mathrm{kg}^{-1}$ of soil did not have significant influence on the content of available forms of iron, manganese, zinc, copper and boron in the herbicide fallow strips or in the arable $(0-20 \mathrm{~cm})$ and subarable $(20-40 \mathrm{~cm})$ soil layer.

2. The potassium fertilizer forms affected the zinc concentration in soil. Application of potassium sulfate resulted in an increase in the zinc concentration in arable and subarable soil layers in comparison with potassium chloride and nitrate. Different potassium fertilizers forms had no influence on the iron, manganese, copper and boron concentration in soil. 
3. The increase in the content of available potassium forms from 120 to $200 \mathrm{mg} \mathrm{K} \cdot \mathrm{kg}^{-1}$ of soil reduced significantly the concentration of manganese in leaves of apple trees. No significant interaction between increasing levels of potassium content in soil and concentration of iron, cooper, zinc and boron in apple leaves was found

\section{REFERENCES}

Gąstoє M., SkRzyŃski J. 2006. Influence of different dwarfing methods on content of microelements in apple tree organs. Scientific works of the Lithuanian Institute of Horticulture and Lithuanian University of Agriculture, 25(3): 262-272

JAKUBUs M., 2001. Zawartość siarki siarczanowej $w$ glebach uprawnych oraz wptyw wybranych czynników ja determinujacych [Content of sulphate sulphur in arable soils and the influence of some factors which determine its level]. Rocz. AR Poznań, 335: 35-47 [in Polish]

Komosa A., Stafecka A. 2002. Zawartości wskaźnikowe sktadników pokarmowych dla gleb sadowniczych analizowanych metoda uniwersalna [Index contents of nutrients for orchard soils analysed with the universal method]. Rocz. AR Poznań, 341:, Ogrodnictwo, 35: 105-116. [in Polish]

Komosa A., SzewczuK A., 2002. Effect of soil potassium level and different potassium fertilizer form on nutritional status, growth and field of apple trees in the first three years after planting. J. Fruit Ornamental Plant Res., 10: 41-54.

LIPECKI M., JADCZUK E. 1998. Wptyw dawek $i$ sposobu nawożenia potasem na poziom odżywienia mineralnego jabtoni [Effect of rates and fertilization techniques on the mineral nutrition level of apple trees]. Zesz. Nauk. AR Kraków, 333: 499-501. [in Polish]

Leszczyński A., SAdowski A. 1990. Response of apple rootstock and of apple maiden trees to different levels of potassium supply in sand culture. Acta Hort., 274: 277-286

Metody badań laboratoryjnych $w$ stacjach chemiczno-rolniczych. Cz.II. Badanie materiatu roślinnego [Laboratory research methods in chemical and agricultural stations. Part II. Analyses of plant material]. IUNG Puławy, 1972. ss. 25-83. [in Polish]

Metody badań laboratoryjnych $w$ stacjach chemiczno-rolniczych. Cz. III. Badanie gleb, ziem $i$ podtoży spod warzyw $i$ kwiatów oraz części wskaźnikowych roślin $w$ celach diagnostycznych[Laboratory research methods in chemical and agricultural stations. Part III. Analyses of soils, earth and substrates under vegetables and fruit as well as index organs of plants for diagnostic purposes]. IUNG, Puławy, 1983. ss. 28-81. [in Polish]

PACHOlaK E., 1984. Wptyw nawożenia $i$ nawadniania na zawartość sktadników pokarmowych $w$ liściach drzew $i w$ glebie sadu jabłoniowego [Influence of fertilization and irrigation on the content of nutrients in tree leaves and in soil of an apple orchard]. Pr. Kom. Nauk Rol. Leś. PTNP 57: 233-243. [in Polish]

Pietranek A., JadCzuk E., Mineral Status of 'Katja' apple trees depending on irrigation, fertlization and rootstock. Acta Sci. Pol. Hort. Cultus, 4(1): 69-76.

Szewczuk A., Komosa A., Gudarowska E. 2008. Effect of soil potassium levels and different potassium fertilizer forms on yield and storability of 'Golden Delicious' apples. Acta Sci. Pol. Hort. Cultus, 7(2): 53-59.

Szücs E., 2005. Some aspects of integrated plant nutrition in orchard. Acta. Sci. Pol. Hort. Cultus, 4 (1): 47-57 